\title{
Vascular and cardiac function in young adults with classical congenital adrenal hyperplasia
}

\author{
Ocena funkcji serca oraz naczyń u pacjentów z klasyczną postacią wrodzonego \\ przerostu nadnerczy
}

\author{
Joanna Wierzbicka-Chmiel', Artur Chmiel' ${ }^{2}$, Sławomir Rychlik², Monika Ogrodowczyk-Bobik', \\ Bogdan Marek ${ }^{1,3}$, Dariusz Kajdaniuk ${ }^{1,3}$
}

${ }^{1}$ Department of Endocrinology, Hospital Rybnik, Poland

${ }^{2}$ Department of Cardiology, Hospital Rybnik, Poland

${ }^{3}$ Department of Pathophysiology and Endocrinology, School of Medicine in Zabrze, Medical University of Silesia, Katowice, Poland

\begin{abstract}
Introduction: Patients with classical congenital adrenal hyperplasia (CAH) have increased cardiovascular risk, but the vascular and cardiac function during longitudinal corticoids replacement therapy is not known thoroughly.

Material and methods: Cross-sectional study of 19 Caucasian adults with CAH (age $23.7 \pm 3.8$ years; twelve males) compared to 20 healthy volunteers matched for origin, sex, age, and body mass index (BMI). All of the participants were assessed for flow mediated dilatation of the brachial artery (FMD), intima-media thickness of the common carotid artery (cIMT) and common femoral artery (fIMT), standard echocardiography, and global longitudinal left ventricular function using two-dimensional speckle-tracking echocardiography (LSTE). Results: The patients with CAH, compared with controls, had decreased FMD $(9.4 \pm 3.9$ vs. $19.8 \pm 5.2 ; \mathrm{p}<0.01)$, and the difference was still significant after correction for potential confounders. cIMT and fIMT were higher in the CAH group at baseline (for cIMT $0.47 \pm 0.4$ mm vs. $0.40 \pm 0.03 \mathrm{~mm}$; p < 0.01, for fIMT $0.47 \pm 0.05 \mathrm{~mm}$ vs. $0.41 \pm 0.04 \mathrm{~mm} ; \mathrm{p}<0.01$ ) but not after correction for potential confounders. The CAH subjects, compared with controls, had normal or similar left ventricular (LV) ejection fraction and LV mass index. The mean absolute value of LSTE differed in the CAH patients compared with controls $(-20.5 \% \pm 1.2 \mathrm{vs.}-22.5 \% \pm 1.7$; $\mathrm{p}<0.01)$, but it was still within the normal range.

Conclusions: Young adults with CAH and glucocorticoid long-lasting treatment had impaired FMD, an insignificant increase of IMT, and subclinical changes in LV diastolic function in echocardiography. (Endokrynol Pol 2017; 68 (5): 505-511)
\end{abstract}

Key words: congenital adrenal hyperplasia, flow-mediated dilatation, intima-media thickness, left ventricular function

\section{Streszczenie}

Wstęp: Pacjenci z klasyczną postacią wrodzonego przerostu nadnerczy (congenital adrenal hyperplasia, CAH) charakteryzują się zwiększonym ryzykiem sercowo-naczyniowym, jednak funkcja naczyń oraz serca podczas długotrwałej substytucyjnej terapii glikokortykoidami nie została jednoznacznie określona.

Pacjenci i metody: W badaniu obserwacyjnym, 19 dorosłych rasy białej z CAH (wiek 23,7 \pm 3,8 roku; 12 mężczyzn) porównywano z 20 zdrowymi ochotnikami dobranymi pod względem pochodzenia, płci, wieku i współczynnika masy ciała. U wszystkich uczestników badania oceniono wazodylatację tętnicy ramiennej indukowaną przepływem (flow mediated dilatation, FMD), grubość kompleksu intima-media tętnicy szyjnej wspólnej (intima-media thickness of the common carotid artery, cIMT) oraz tętnicy udowej (common femoral artery, fIMT) wspólnej oraz oceniono odkształcenie lewej komory przy zastosowaniu techniki śledzenia markerów akustycznych (longitudinal speckle-tracking echocardiography, LSTE).

Wyniki: U pacjentów z CAH w porównaniu z grupą kontrolną zaobserwowano mniejszą wartość FMD $(9,4 \pm 3,9$ vs. 19,8 \pm 5,2; p < 0,01) i różnica ta była nadal istotna po uwzględnieniu wpływu średnicy tętnicy ramiennej. Wyjściowo cIMT i fIMT były większe u pacjentów z CAH (cIMT 0,47 \pm 0,4 mm vs. $0.40 \pm 0,03 \mathrm{~mm}, \mathrm{p}<0,01$; fIMT 0,47 $\pm 0,05 \mathrm{~mm}$ vs. 0,41 $\pm 0,04 \mathrm{~mm}, \mathrm{p}<0,01$ ), ale nie po uwzględnieniu klasycznych czynników ryzyka sercowo-naczyniowego. Frakcja wyrzutowa oraz masa lewej komory w obu grupach były podobne. Średnia wartość LSTE była różna u pacjentów z CAH z porównaniu z grupą kontrolną $(-20,5 \pm 1,2 \%$ vs. $-22,5 \pm 1,7 \%$, p < 0,01), ale nadal pozostawała w granicach normy.

Wnioski: U młodych dorosłych z CAH długotrwale leczonych glikokortykosteroidami FMD jest upośledzona, występuje nieistotne pogrubienie cIMT i fIMT oraz podkliniczne zmiany w funkcji rozkurczowej serca w echokardiografii. (Endokrynol Pol 2017; 68 (5): 505-511)

Słowa kluczowe: wrodzony przerost nadnerczy, wazodylatacja indukowana przepływem, grubość kompleksu intima-media, funkcja lewej komory

This research did not receive any specific grant from any funding agency in the public, commercial or not-for-profit sector. 


\section{Introduction}

Congenital adrenal hyperplasia (CAH) is a group of autosomal recessive disorders characterised by a defect in cortisol biosynthesis mainly due to 21-hydroxylase deficiency (21-OHD) [1]. About 1 in 10,000-18,000 children are born with CAH. The goal of treatment is to return hormone levels to normal, or near normal, which is accomplished by taking a form of cortisol. Optimal therapeutic regimens are difficult to achieve, and often complications related to glucocorticoid and/ /or androgen excess arise. Therefore, abnormalities in lipid and glucose metabolism, body fat mass, insulin, leptin, and blood pressure levels have been reported in patients with 21-OHD, with potential long-term complications in life [2-5]. Overtreatment or undertreatment can affect cardiac and vascular function. There is increasing evidence that endothelial dysfunction and vascular changes are precursors of clinically detectable atherosclerosis and improve prediction of future cardiovascular (CV) events [6,7]. It has been described that adolescent children with $\mathrm{CAH}$ present vascular dysfunction measured by flow-mediated dilatation of the brachial artery (FMD) and increased carotid intima media thickness (cIMT) [8-11]. cIMT remains higher in adults $[3,12]$. The echocardiographic changes in young patients with CAH have been poorly described; there is only limited information concerning the increase of the left ventricular mass index (LVMI) and left ventricular (LV) dysfunction compared with controls [11, 13]. Poor hormonal control, especially overtreatment, is common among patients with $\mathrm{CAH}$, and it seems to determine the higher rate of $\mathrm{CV}$ events in this group [14]. The influence and the results of long-term corticosteroid and fludrocortisone replacement therapy on vascular and cardiac function in adults with CAH have not been established yet.

\section{Material and methods}

We included into cross sectional study 19 young Caucasian adults with $\mathrm{CAH}$, with mean age $23.7 \pm 3.8$ years, (12 males), all salt wasting (SW) due to 21-OHD, who were treated at the Department of Endocrinology in Rybnik, Poland for the first time. All of the participants signed a written, informed consent after receiving information about the study. The diagnosis of $\mathrm{CAH}$ was based on clinical and biochemical criteria in new-borns and all the patients had experienced a SW adrenal crisis in the neonatal period. The individuals had been treated continuously from the time of diagnosis and none of them was cured in utero with dexamethasone. The accuracy of the therapy was monitored periodically on the basis of clinical and laboratory data, according to the guidelines $[15,16]$. All the patients received corticoid replacement therapy, one woman took oral contraceptive pills, and none of the patients used additional medication. The control group constituted 20 healthy volunteers without cardiovascular diseases (CVD) matched for origin, age, and body mass index (age $23.2 \pm 2.6$ years; 12 males), enrolled in the same region of Poland.

\section{Data sources}

The clinical characteristics of study patients included medical history (family history, concomitant diseases, present pharmacotherapy, smoking status) and physical examination: resting blood pressure (BP), heart rate (HR), body mass index (BMI), and height, waist, and hip circumference (WHR) using standard methods. Anthropometric measurements were obtained in the morning. The mean of three BP measurements taken with sphygmomanometer on separate occasions was considered.

\section{Laboratory tests}

Blood samples were drawn from the peripheral vein of supine individuals at 6:00 a.m. for measurements of hormones. Total cholesterol (T-Ch), high-density lipoprotein cholesterol fractions (HDL-Ch), low-density lipoprotein cholesterol fractions (LDL-Ch), triglycerides (TGL), creatinine, and serum glucose levels, were measured using routine methods. The oral glucose tolerance test (OGTT) after an overnight fast for at least $10 \mathrm{~h}$ and after oral administration of $75 \mathrm{~g}$ glucose was performed. Serum levels of total testosterone (TT), 17-hydroxyprogesterone (17-OHP), and androstenedione were measured using an electrochemiluminescence immunoassay (Roche Diagnostics Manheim, Germany). Plasma renin activity (RRA) was measured using radioimmunoassay. Glucocorticoid dose equivalencies were calculated based on their growth-suppressing effects in comparison to hydrocortisone. The prednisone dose was multiplied by five, and the dexamethasone dose was multiplied by $80[17,18]$. The biochemical CVD risks factors were performed in patients and controls.

\section{Definitions}

17-OHP was considered suppressed if below $100 \mathrm{ng} / \mathrm{dL}$. Androstenedione, TT, and PRA were categories as suppressed, normal, or elevated based on the respective sex-specific normal ranges. The overweight was defined as BMI between 25 and $29.9 \mathrm{~kg} / \mathrm{m}^{2}$, and obesity at minumum $30 \mathrm{~kg} / \mathrm{m}^{2}$. Metabolic syndrome was recognised according to the International Diabetes Federation (IDF) definition [19]. Impaired glucose tolerance (IGT) was categorised as two-hour glucose levels of 7.8 to $11.0 \mathrm{mmol} / \mathrm{L}$ during the OGTT. Central obesity was 
recognised when waist circumference was $\geq 94 \mathrm{~cm}$ (male) and $\geq 80 \mathrm{~cm}$ (females); dyslipidaemia was identified as follows: T-Ch $>5.0 \mathrm{mmol} / \mathrm{L}$ or LDL-Ch $>3.0 \mathrm{mmol} / \mathrm{L}$ or HDL-Ch $<1.0 \mathrm{mmol} / \mathrm{L}$ (male), $<1.2 \mathrm{mmol} / \mathrm{L}$ (female) or TG $>1.7 \mathrm{mmol} / \mathrm{L}$. The normal range left mass index (LVMI) was defined as $<125 \mathrm{~g} / \mathrm{m}^{2}$ (male) and $<110 \mathrm{~g} / \mathrm{m}^{2}$ (female). The normal left ventricular ejection fraction (LVEF) wad defined as equal to or more than $55 \%$ [20].

\section{Ultrasound assessment}

Echocardiography was performed in all of the patients according to the guidelines of the European Society of Echocardiography. Two-dimensional (2D) M-mode transthoracic echocardiography (TTE) was used in all patients to measure the LV dimensions in the left parasternal long-axis view. The values of LV end-diastolic volumes (LV EDV) and LV end-systolic volumes (LV ESV) were measured, and the LVEF was obtained using Simpson's method [21]. The left ventricular mass (LVM) was calculated from the measurement of LV by using the truncated ellipsoid methods by 2D echocardiography, in grams [22]. The LVMI representing LVM corrected for body surface area (BSA) was calculated. Mitral inflow was assessed in the apical four-chamber view, using pulsed-wave Doppler echocardiography, with the Doppler beam aligned parallel to the direction of flow and the sample volume at the leaflet tips. Measurements included peak E and A velocities. Doppler tissue imaging of the mitral annulus was obtained from the apical four-chamber view using a 1-2-mm sample volume placed in the septal and lateral sides of the mitral annulus valve, and then the average value was obtained. The ratio $\mathrm{E} / \mathrm{e}^{\prime}$ including the mitral inflow E velocity to tissue Doppler was obtained as a marker of LV filling pressure [23].

Myocardial tissue deformation was analysed offline using commercially available software (QLAB Philips) using recorded $2 \mathrm{D}$ grey-scale images. The software analysed the speckles within the myocardium and calculated segmental strain. The peak longitudinal strain echocardiography (STE) was calculated as the average of peak values for each of the segments in the apical two-chamber, four-chamber, and five-chamber views. The values of inter- and intra-observer variability in analysis of patients' recordings were $90 \%$ and $94 \%$, respectively. Among all the strain parameters, the longitudinal strain is more reproducible than the radial and circumferential strain and rotation. Similarly, the global strain has much better reproducibility than the segmental strain.

\section{Flow-mediated dilatation}

The measurements of the brachial artery FMD were conducted in a quiet, temperature-controlled room between 9.00 and $11.00 \mathrm{am}$. Patients underwent evaluation after at least 10-minute rest in a supine position. Experienced investigators took measurements in a B-mode presentation using a high-frequency ultrasound system (Philips HD 15) equipped with vascular software for two-dimensional (2D) imaging, colour and spectral Doppler, an internal electrocardiogram monitor, and a high-frequency vascular transducer (multiple-frequency: 7-10 MHz). The brachial artery diameter (Bad) of the dominant forearm (in the case of the radial access the secondary artery) was visualised above the antecubital fossa in a longitudinal plane, with a sphygmomanometer cuff on the proximal portion of the arm. The brachial artery diameter was described as a minimal distance between ' $\mathrm{m}$ ' lines, from the anterior to the posterior wall of the artery. Images were acquired with ECG gating, with measurements made in end diastole, which corresponds to the onset of the $\mathrm{R}$ wave. The study was performed in three stages: stage 1 : baseline brachial artery diameter and flow measurements were taken, and the mean average was calculated for each subject; stage 2: the sphygmomanometer cuff was inflated to $200 \mathrm{mmHg}$ to occlude arterial inflow for 3 min; stage 3: brachial artery diameter and blood flow were obtained during 50-60 seconds after cuff deflation, and the mean of the values were calculated. Taking these two measurements into consideration (baseline and after cuff deflation), the percentage increase in the artery diameter in comparison to baseline results was calculated - FMD [24, 25]. The values of inter- and intra-observer variability in analysis of patients' recordings were $89 \%$ and $90 \%$, respectively. Because FMD mostly depends on Bad, the FAD x Bad index was also calculated [26].

\section{Intima media thickness of the common carotid artery and common femoral artery}

Intima media thickness of the common carotid artery was obtained with the patient lying in the supine position (Philips HD15). cIMT measurements were performed over a distance of $10 \mathrm{~mm}$ on the posterior wall of each common carotid artery (CCA) before the bulb. Three different longitudinal images (anterior oblique, lateral, and posterior oblique) for each CCA were produced. In the case of the plaque in the measurement side, which was defined as a localised protrusion into the vessel lumen with thickening of the vessel wall of $>50 \%$ compared to the adjustment cIMT, the measurement was passed over [27]. All the measurements were conducted in the end diastolic phase of the cardiac cycle. cIMT-analysis was obtained by automatic technique using QLAB Philips system after completed examination, and presented as a mean value from six measurements. QLAB's IMT measurement plug-in 
was used to increase the consistency and reliability of cIMT measurements. The same technique was used to evaluate the intima media thickness of the common femoral artery (fIMT).

\section{Statistical analysis}

Statistical analysis was performed by the application of MedCalc Statistical Software version 14.12.0 (MedCalc Software bvba, Ostend, Belgium). All of the text and table results are expressed as mean \pm standard deviation (SD) or median and interquartile range (IQR) or number and percentage. The normal distribution of the results was analysed using the Kolmogorov-Smironov test. In the case of abnormal distribution a logarithmic transformation was introduced. The calculation of Coefficient of Variation (CV) from duplicate measurements was made. Baseline clinical parameters and the results of accessory investigations were compared using the t-test or U Mann-Whitney test. Categorical variables were compared using Fisher's exact test. To determine the relationship between the dose of corticosteroids and FMD, cIMT, and fIMT Pearson correlations after logarithmic transformation were used. To compare the FMD and intima media thickness (IMT) values between groups after adjusting for potential cofounders, the ANCOVA test with Bonferroni correction was introduced. Statistical significance was defined as $\mathrm{p}<0.05$.

\section{Results}

\section{Treatment and adrenal hormone status}

As expected, all the patients were treated with the glucocorticoid: 11 (58\%) of them received hydrocortisone, seven $(37 \%)$ hydrocortisone and dexamethasone, and one $(5 \%)$ only dexamethasone. The mean glucocorticoid equivalence dose was $20.0 \pm 6.0 \mathrm{mg} / \mathrm{m}^{2}$. Seventy-three per cent (14 patients) were cured by fludrocortisone, with median dose $29 \mu \mathrm{g} / \mathrm{m}^{2}$ (IQR: 26-58).

Overtreatment or undertreatment was common in the analysed group of patients. Only 36\% had acceptable hormonal status based on early morning 17-OHP concentration between 100 and 1200 ng/dL (mean 201 $\pm 211 \mathrm{ng} / \mathrm{dL}$ ). Approximately half of the patients had androstenedione level in normal range (median 2.82 $\mathrm{ng} / \mathrm{ml}$, IQR: 0.75-13.9). In addition, the elevated testosterone concentration adjusted for sex was detected in three patients (median $3.35 \mathrm{ng} / \mathrm{mL} \pm 2.9$ ). The PRA was in normal range only in $30 \%$ of the patients.

\section{Cardiovascular risk factors}

Eleven patients (58\%) had normal BMI, five (26\%) were overweight, while three $(16 \%)$ were obese. The central obesity was recognised in three $(15 \%)$, individuals and metabolic syndrome according IDF criteria in two
Table I. Clinical characteristics of the study group

Tabela I. Charakterystyka kliniczna badanej grupy

\begin{tabular}{llll}
\hline Variables & CAH (N = 19) & Control (N = 20) & P value \\
\hline Age (years) & $23.7 \pm 3.8$ & $23.2 \pm 2.6$ & 0.60 \\
\hline BMl $\left[\mathrm{kg} / \mathrm{m}^{2}\right]$ & $24.9 \pm 5.1$ & $23.5 \pm 3.3$ & 0.30 \\
\hline High [cm] & $162 \pm 8$ & $168 \pm 7$ & 0.03 \\
\hline Weight $[\mathrm{kg}]$ & $63.3 \pm 13.6$ & $66.4 \pm 12.7$ & 0.80 \\
\hline Waist to hip ratio & $0.84 \pm 0.05$ & $0.82 \pm 0.08$ & 0.31 \\
\hline SBP [mmHg] & $109 \pm 12$ & $111 \pm 9$ & 0.63 \\
\hline DBP [mmHg] & $69 \pm 9$ & $72 \pm 7$ & 0.29 \\
\hline TCh [mmo//l] & $4.5 \pm 0.9$ & $4.8 \pm 0.8$ & 0.21 \\
\hline LDL-Ch [mmol/l] & $2.7 \pm 0.7$ & $2.9 \pm 0.6$ & 0.49 \\
\hline HDL-Ch [mmol/l] & $1.4 \pm 0.3$ & $1.5 \pm 0.3$ & 0.29 \\
\hline TG [mmol/l] & $1.3 \pm 0.6$ & $1.0 \pm 0.5$ & 0.13 \\
\hline Active smoking & $2(11 \%)$ & $3(15 \%)$ & 1.0 \\
\hline
\end{tabular}

Abbreviations: $\mathrm{CAH}$, congenital adrenal hyperplasia; BMI, body mass index; SBP, systolic blood pressure; DBP, diastolic blood pressure; TCh, total cholesterol; LDL-Ch, low density lipoprotein cholesterol; HDL-Ch, high densisty lipoprotein cholesterol; TG, triglicerydes

patients. Dyslipidaemia was present in $10(57 \%)$ patients, nobody had plasma fasting glucose $\geq 5.6 \mathrm{mmol} / \mathrm{L}$, but three patients exhibited IGT in OGGT. CAH patients did not statistically differ with controls in CVD risk factors, and the global results are presented in Table I and II.

\section{Vascular changes}

The patients with $\mathrm{CAH}$, compared with the control group, had decreased mean FMD $(9.4 \pm 3.9$ vs. $19.8 \pm$ 5.2; $\mathrm{p}<0.01)$, and the difference was still significant after correction for potential confounders such as: brachial artery diameter, age, sex, BMI, total cholesterol level, smoking status, the dose of corticosteroid, and fludrocortisone (mean 9.2; SE 2.6 vs. 19.4; SE 2.4; $\mathrm{p}=$ 0.03). The FMD $x$ Bad index was also different in the CAH group $(\mathrm{p}<0.1)$. The cIMT and fIMT was higher in the CAH group at baseline (for cIMT $0.47 \pm 0.4 \mathrm{~mm}$ vs. $0.40 \pm 0.03 \mathrm{~mm} ; \mathrm{p}<0.01$, for fIMT $0.47 \pm 0.05 \mathrm{~mm}$ vs. $0.41 \pm 0.04 \mathrm{~mm} ; \mathrm{p}<0.01)$. The difference was not significant after correction for potential confounders such as: age, sex, BMI, the dose of corticosteroid and fludrocortisone, total cholesterol level, and smoking status (for cIMT $0.45 \mathrm{~mm}$, SE 0.02 vs. $0.42 \mathrm{~mm}$, SE 0.02; $\mathrm{p}=0.46$, for fIMT $0.46 \mathrm{~mm}$, SE 0.02 vs. $0.41 \mathrm{~mm}$, SE 0.02; $\mathrm{p}=0.14)$. There was no correlation between cumulative steroids dose and cIMT, fIMT, and FMD (Table III).

\section{Echocardiographic changes}

All the CAH subjects compared with controls had normal and similar LVEF: $64 \pm 4$ vs. $65 \pm 4 ; \mathrm{p}=0.60$ and LVMI: $90.4 \mathrm{~g} / \mathrm{m}^{2} \pm 15$ vs. $87.4 \mathrm{~g} / \mathrm{m}^{2} \pm 12 ; \mathrm{p}=0.50$. 
Table II. Cardiovascular risk factors in the study group Tabela II. Czynniki ryzyka sercowo-naczyniowego w badanej grupie

\begin{tabular}{llll}
\hline Variables & CAH (N = 19) & Control (N = 20) & P value \\
\hline Active smoking & $2(11 \%)$ & $3(15 \%)$ & 1.0 \\
\hline Dyslipidemia & $10(53 \%)$ & $9(45 \%)$ & 0.75 \\
\hline Hypertension & 0 & 0 & - \\
\hline IGT & $4(21 \%)$ & $1(5 \%)$ & 0.18 \\
\hline Central obesity & $3(16 \%)$ & $2(10 \%)$ & 0.66 \\
\hline $\begin{array}{l}\text { Normal weight/ } \\
\text { loverweight/ } \\
\text { /obesity }\end{array}$ & $11 / 5 / 3$ & $13 / 6 / 1$ & 0.54 \\
$\begin{array}{l}\text { Metabolic } \\
\text { symdrome }\end{array}$ & $2(11 \%)$ & $2(10 \%)$ & \\
\hline
\end{tabular}

Values are given as number and percentage. Abbreviations: $\mathrm{CAH}$, congenital adrenal hyperplasia; IGT, impaired glucose tolerance

Table III. Value of FMD, cIMT, fIMT in the study group Tabela III. Wartość FMD, cIMT w badanej grupie

\begin{tabular}{|c|c|c|c|c|}
\hline Variables & Overall & Control & CAH & $P$ value \\
\hline & $\mathbf{n}=\mathbf{3 9}$ & $\begin{array}{l}n=19 \\
(48 \%)\end{array}$ & $\begin{array}{l}n=20 \\
(52 \%)\end{array}$ & \\
\hline Bad [mma $]$ & $3.2 \pm 0.45$ & $3.2 \pm 0.40$ & $3.2 \pm 0.51$ & 0.88 \\
\hline $\mathrm{FMD}^{\mathrm{a}}$ & $13.5 \pm 6.7$ & $9.4 \pm 3.9$ & $19.8 \pm 5.2$ & $<0.01$ \\
\hline $\mathrm{FMD}^{\mathrm{b}}$ & - & $9.2 ; 2.6$ & $19.9 ; 2.4$ & 0.03 \\
\hline $\begin{array}{l}\text { FMDxBad } \\
\text { index }\end{array}$ & $46 \pm 21$ & $30 \pm 13$ & $62 \pm 16$ & $<0.01$ \\
\hline clMT $\left[\mathrm{mm}^{\mathrm{a}}\right]$ & $0.44 \pm 0.05$ & $0.47 \pm 0.04$ & $0.40 \pm 0.03$ & $<0.01$ \\
\hline cIMT $\left[\mathrm{mm}^{\mathrm{c}}\right]$ & - & $0.45 ; 0.02$ & $0.42 ; 0.02$ & 0.46 \\
\hline fIMT [mmª & $0.43 \pm 0.05$ & $0.47 \pm 0.05$ & $0.41 \pm 0.04$ & $<0.01$ \\
\hline $\mathrm{fIMT}\left[\mathrm{mm}^{\mathrm{c}}\right]$ & - & $0.46 ; 0.02$ & $0.41 ; 0.02$ & 0.14 \\
\hline
\end{tabular}

aalues are given as mean $\pm S D$ or median (interquartile range) ${ }^{\mathrm{b} p} \mathrm{p}$ value after correction for potential confounders such as: Bad, age, sex, BMI, the dose of corticosteroid and fludrocortisone, total cholesterol level, smoking status, values are given as estimated marginal means and standard error ${ }^{c} p$ value after correction for potential confounders such as: age, sex, BMI, the dose of corticosteroid and fludrocortisone, total cholesterol level, smoking status, values are given as estimated marginal means and standard error Abbreviations: $\mathrm{CAH}$, congenital adrenal hyperplasia; Bad, brachial artery diameter; FMD, flow mediated dilatation; cIMT, intima-media thickness of common carotid artery, fIMT, intima-media thickness of common femoral artery

Doppler tissue imaging of the mitral annulus was lower in the CAH group: $14.5 \pm 3.3 \mathrm{~cm} / \mathrm{s}$ vs. $16.8 \pm 3.0 \mathrm{~cm} / \mathrm{s}$, $\mathrm{p}=0.03$, but the value was still within the normal range. The mean absolute value of LSTE differed in the CAH patients compared with controls $(-20.5 \% \pm 1.2 \mathrm{vs}$. $-22.5 \% \pm 1.7 ; \mathrm{p}<0.01)$ (Table IV).

\section{Correlation results}

We found the positive correlation between fIMT and TT in the study group $(\mathrm{r}=0.43 ; \mathrm{p}=0.04)$, for cIMT
Table IV. Echocardiographic characteristics of the study group Tabela IV. Charakterystyka echokardiograficzna w badanej grupie

\begin{tabular}{llll}
\hline Variables & CAH $(\mathbf{N}=\mathbf{1 9})$ & Control $(\mathbf{N}=\mathbf{2 0})$ & P value \\
\hline LVEF $(\%)$ & $64 \pm 4$ & $65 \pm 4$ & 0.60 \\
\hline LVMI $\left[\mathrm{g} / \mathrm{m}^{2}\right]$ & $90.4 \pm 15$ & $87.4 \pm 12$ & 0.50 \\
\hline $\mathrm{e}^{\prime}[\mathrm{cm} / \mathrm{s}]$ & $14.5 \pm 3.3$ & $16.8 \pm 3$ & 0.03 \\
\hline E/e' ratio & $5.9 \pm 1.6$ & $4.9 \pm 0.95$ & 0.08 \\
\hline LSTE $(\%)$ & $-20.5 \pm 1.2$ & $22.5 \pm 1.7$ & $<0.01$ \\
\hline
\end{tabular}

Abbreviations: $\mathrm{CAH}$, congenital adrenal hyperplasia; LVEF, left ventricular ejection fraction; LVMI, left ventricular mass index, $e^{\prime}$ average value of the Doppler tissue imaging of the mitral annulus; $\mathrm{E} / \mathrm{e}^{\prime}$, the ratios include the mitral inflow $\mathrm{E}$ velocity to tissue Doppler e'; LSTE, longitude speckle-tracking echocardiography

$(\mathrm{r}=0.33 ; \mathrm{p}=0.10)$. No additional significant correlation emerged between 17-OHP, androstenedione, cumulative glucocorticoids doses, and FMD, FMDxBad index, cIMT, fIMT, and echocardiography parameters.

\section{Discussion}

The study population did not statistically differ in classic CVD risk factors, and metabolic profiles were comparable to apparently healthy individuals in the same region of Poland [28]. Despite this fact, we observed more vascular changes in the study group. Harrington et al. described impaired FMD in CAH adolescents as being comparable to obese control patients [8]. The issue of impaired FMD in overweight has not been solved explicitly. In CAH patients probably the reason for endothelial dysfunction is not the obesity itself, but the higher proportion of proinflammatory visceral adipose tissue to subcutaneous adipose tissue and insulin resistance $[4,10,29]$, as well as the excess of androgens: TT and androstenedione influences the endothelial function. Sander et al. revealed in a small group of young hypogonadal but otherwise healthy men, that receiving testosterone depot in short-term follow-up caused a significant decrease in FMD [30]. Similarly, self-administration of anabolic-androgenic steroids was associated with endothelial dysfunction in male body builders [31]. The metabolic profile of the analysed group was not optimal, which, unfortunately, is quite common in the CAH population [14]. The question of whether optimal hormonal status of CAH patients improves endothelial function, which is sensitive to minor homeostasis disturbances, remains unanswered [32].

Ultrasound assessment of cIMT is a well-established examination that perfectly correlates with $\mathrm{CV}$ risk estimated by means of Systematic COronary Risk Evaluation (SCORE scale), which is the perfect tool for 
predicting the risk of CV death [27]. The present study revealed increased cIMT and fIMT in CAH patients, similarly to other results $[3,11,12]$, but after correction for classic CVD risk factors and substitution doses of steroids the value was not statistically important. This reveals the possible relationship between IMT and glucocorticoid replacement therapy. Moreover, the IMT of all the patients was within the normal limits, and any atherosclerotic plaque was detected in the common femoral artery as well as in the CCA. Additionally, IMT values of our patients, measured by an automatic method, were substantially lower than data from previous publications, in which IMT was estimated by operators, who might spontaneously overestimate IMT values [3].

We revealed positive correlation between cIMT and TT in CAH patients for the first time. In 2015 Khazai et al. in a male cohort demonstrated that lower TT levels compared to higher levels after adjustment for CVD risk factors were associated with lower cIMT [33].

Children with CAH had recognised increased LVMI [11], but we did not observe such a relationship in our adult population. Bofing et al., in CAH children, especially SW, observed transient-hypertension, but the prevalence of hypertension decreased with age [5], which might be responsible for transient left ventricular mass increase. Their participants had normal LVEF but statistically worse left ventricular regional myocardial function when using two-dimensional speckle tracking echocardiography in comparison to controls. The clinical importance of this difference remains unknown. STE can accurately detect subtle changes in the myocardial function and is much more sensitive to the early myocardial damage than any of the other deformation parameters [34]. It has been demonstrated that new-borns with CAH showed evidence for cardiac dysfunction at baseline, which reversed with corticosteroid replacement therapy [35].

Our study has some limitations, among which the foremost is the small number of participants, so the power of the study was inappropriate for many clinical endpoints. Moreover, during inclusion the patients were suboptimally treated. On the other hand, the patients came from the same region of Poland and so had similar CVD risk factors associated with ethnicity, diet, and pollution of the natural environment.

In conclusion, we underline that $\mathrm{CAH}$ are prone to CVD much more than could be due to classic risk scales. In addition, the echocardiographic changes, especially in diastole function, might be a signal for development of heart failure in older age. The question of whether optimal therapy might reverse this trend, remains unanswered, especially as recommended drugs such as aldosterone antagonists and angiotensin-converting-enzyme inhibitors may be not effective in $\mathrm{CAH}$ patients.

\section{References}

1. Merke DP, Bornstein SR. Congenital adrenal hyperplasia. Lancet. 2005; 365: 2125-2136, doi: 10.1016/S0140-6736(05)66736-0, indexed in Pubmed: $\underline{15964450 .}$.

2. Mooij C, Kroese J, Claahsen - van der GH, et al. Unfavorable trends in cardiovascular and metabolic risk in pediatric and adult patients with congenital adrenal hyperplasia? Clin Endocrinol. 2010; 73: 137-146, doi: 10.1111/j.1365-2265.2009.03690.x, indexed in Pubmed: 19719762.

3. Sartorato P, Zulian E, Benedini S, et al. Cardiovascular risk factors and ultrasound evaluation of intima-media thickness at common carotids, carotid bulbs, and femoral and abdominal aorta arteries in patients with classic congenital adrenal hyperplasia due to 21-hydroxylase deficiency. J Clin Endocrinol Metab. 2007; 92: 1015-1018, doi: 10.1210/jc.2006-1711, indexed in Pubmed: 17200174.

4. Kim M, Ryabets-Lienhard A, Dao-Tran A, et al. Increased Abdominal Adiposity in Adolescents and Young Adults With Classical Congenital Adrenal Hyperplasia due to 21-Hydroxylase Deficiency. J Clin Endocrinol Metab. 2015; 100: 1153-1159, doi: 10.1210/jc.2014-4033, indexed in Pubmed: 26062016.

5. Bonfig W, Schwarz HP. Blood pressure, fludrocortisone dose and plasma renin activity in children with classic congenital adrenal hyperplasia due to 21-hydroxylase deficiency followed from birth to 4 years of age. Clin Endocrinol(Oxford). 2014; 81: 871-875, doi: 10.1111/cen.12498, indexed in Pubmed: 24818525

6. Bonetti PO, Lerman LO, Lerman A. Endothelial dysfunction: a marker of atherosclerotic risk. Arterioscler Thromb Vasc Bio. 2003; 23: 168-175, doi: 10.1161/01.atv.0000051384.43104.fc, indexed in Pubmed: 12588755.

7. Lorenz MW, Markus HS, Bots ML, et al. Prediction of clinical cardiovascular events with carotid intima-media thickness: a systematic review and meta-analysis. Circulation. 2007; 115: 459-467, doi: 10.1161/CIRCULATIONAHA.106.628875, indexed in Pubmed: 17242284.

8. Harrington J, Peña AS, Gent R, et al. Adolescents with congenital adrenal hyperplasia because of 21-hydroxylase deficiency have vascular dysfunction. Clin Endocrinol. 2012; 76: 837-842, doi: 10.1111/j.13652265.2011.04309.x, indexed in Pubmed: 22145701.

9. Wasniewska M, Balsamo A, Valenzise M, et al. Increased large artery intima media thickness in adolescents with either classical or nonclassical congenital adrenal hyperplasia. J Endocrinol Invest. 2013; 36: 12-15, indexed in Pubmed: 22189488.

10. Amr NH, Ahmed AY, Ibrahim YA. Carotid intima media thickness and other cardiovascular risk factors in children with congenital adrenal hyperplasia. J Endocrinol Invest. 2014; 37: 1001-1008, doi: 10.1007/ s40618-014-0148-8, indexed in Pubmed: 25112902.

11. Metwalley K, Farghaly $H$, Sherief T. Left ventricular dysfunction and subclinical atherosclerosis in children with classic congenital adrenal hyperplasia: a single-center study from upper Egypt. Eur J Pediatr. 2015; 175: 405-412.

12. Mnif MF, Kamoun M, Mnif F, et al. Metabolic profile and cardiovascular risk factors in adult patients with congenital adrenal hyperplasia due to 21-hydroxylase deficiency. Indian J Endocrinol Metab. 2012; 16: 939-946, doi: 10.4103/2230-8210.102995, indexed in Pubmed: 23226639.

13. Ubertini G, Bizzarri C, Grossi A, et al. Blood Pressure and Left Ventricular Characteristics in Young Patients with Classical Congenital Adrenal Hyperplasia due to 21-Hydroxylase Deficiency. Int J Pediatr Endocrinol. 2009, doi: 10.1155/2009/383610, indexed in Pubmed: 20169124.

14. Finkielstain GP, Kim MS, Sinaii N, et al. Clinical characteristics of a cohort of 244 patients with congenital adrenal hyperplasia. J Clin Endocrinol Metab. 2012; 97: 4429-4438, doi: 10.1210/jc.2012-2102, indexed in Pubmed: 22990093

15. Schaeffer TL, Tryggestad JB, Mallappa A, et al. An Evidence-Based Model of Multidisciplinary Care for Patients and Families Affected by Classical Congenital Adrenal Hyperplasia due to 21-Hydroxylase Deficiency. Int J Pediatr Endocrinol. 2010, doi: 10.1155/2010/692439, indexed in Pubmed: 20339513

16. Ambroziak U, Bednarczuk T, Ginalska-Malinowska M, et al. Congenital adrenal hyperplasia due to 21-hydroxylase deficiency--management in adults. Endokrynol Pol. 2010; 61: 142-155.

17. Hindmarsh PC. Management of the child with congenital adrenal hyperplasia. Best Pract Res Clin Endocrinol. 2009; 23: 193-208, doi: 10.1016/j. beem.2008.10.010, indexed in Pubmed: 19500763.

18. Rivkees SA, Crawford JD. Dexamethasone treatment of virilizing congenital adrenal hyperplasia: the ability to achieve normal growth. Pediatrics. 2000; 106: 767-773, indexed in Pubmed: 11015521.

19. Alberti K, Zimmet P, Shaw J. IDF Epidemiology Task Force Consensus Group. The metabolic syndrome--a new worldwide definition. Lancet. 2005; 366: 1059-1062, doi: $\underline{10.1016 / \mathrm{s} 0140-6736(05) 67402-8 .}$.

20. Perk J, De Backer G, Gohlke H, et al. European Association for Cardiovascular Prevention \& Rehabilitation (EACPR), ESC Committee for Practice Guidelines (CPG). European Guidelines on cardiovascular disease prevention in clinical practice (version 2012). The Fifth Joint 
Task Force of the European Society of Cardiology and Other Societies on Cardiovascular Disease Prevention in Clinical Practice (constituted by representatives of nine societies and by invited experts). Eur Heart J. 2012; 33: 1635-1701, doi: 10.1093/eurheartj/ehs092, indexed in Pubmed: 22555213.

21. Sahn DJ, DeMaria A, Kisslo J, et al. Recommendations regarding quantitation in M-mode echocardiography: results of a survey of echocardiographic measurements. Circulation. 1978; 58: 1072-1083, doi: 10.1161/01. cir.58.6.1072, indexed in Pubmed: 709763.

22. Roberto M, et al. Lang, Michelle Bierig Chamber quantification. J Am Soc Echocardio. 2005; 18: 1440-1463.

23. Nagueh SF, Appleton CP, Gillebert TC, et al. Recommendations for the Evaluation of Left Ventricular Diastolic Function by Echocardiography. Eur J Echocardio. 2009; 10: 165-193, doi: 10.1093/ejechocard/jep007.

24. Corretti MC, Anderson TJ, Benjamin EJ, et al. Guidelines for the ultrasound assessment of endothelial-dependent flow-mediated vasodilatation of the brachial artery. A report of the international brachial artery reactivity task force. J Am Coll Cardiol. 2002; 39: 57-265.

25. Donald A, Halcox J, Charakida M, et al. Methodological Approaches to Optimize Reproducibility and Power in Clinical Studies of FlowMediated Dilation. J Am Coll Cardiol. 2008; 51: 1959-1964, doi: 10.1016/i. jacc.2008.02.044, indexed in Pubmed: 18482664.

26. Mizia-Stec K, Gasior Z, Mizia M, et al. Flow-mediated dilation and gender in patients with coronary artery disease: arterial size influences gender differences in flow-mediated dilation. Echocardiography. 2007; 24: 1051-1057, doi: 10.1111/j.1540-8175.2007.00531.x, indexed in Pubmed 18001358.

27. Spence J. Measurement of Intima-Media Thickness vs. Carotid Plaque: Uses in Patient Care, Genetic Research and Evaluation of New Therapies. Int J Stroke. 2016; 1: 216-221, doi: 10.1111/j.1747-4949.2006.00068.x indexed in Pubmed: 18706019.
28. Wierzbicka-Chmiel J, Mizia-Stec K, Haberka M, et al. The relationship between cardiovascular risk estimated by use of SCORE system and intima media thickness and flow mediated dilatation in a low risk population. Cardiol J. 2009; 16: 407-412, indexed in Pubmed: 19753518.

29. Williams RM, Deeb A, Ong KK, et al. Insulin sensitivity and body composition in children with classical and nonclassical congenital adrenal hyperplasia. Clin Endocrinol (Oxford). 2010; 72: 155-160, doi: 10.1111/j.1365-2265.2009.03587.x, indexed in Pubmed: 19508608.

30. Sader MA, Griffiths KA, Skilton MR, et al. Physiological testosterone replacement and arterial endothelial function in men. Clin Endocrinol (Oxford) 2003 59: 62-67, doi: 10.1046/j.1365-2265.2003.01796.x, indexed in Pubmed: 12807505.

31. Ebenbichler CF, Sturm W, Gänzer H, et al. Flow-mediated, endotheliumdependent vasodilatation is impaired in male body builders taking anabolic-androgenic steroids. Atherosclerosis. 2001; 158: 483-490, doi: 10.1016/s0021-9150(01)00465-8, indexed in Pubmed: 11583730.

32. Mizia-Stec K, Wieczorek J, Orszulak M, et al. Flow-mediated dilatation (FMD) and prevalence of cardiovascular risk factors: the value of FMD assessment in high risk patients is limited. Kardiol Pol. 2014; 72: 254-261, doi: 10.5603/KP.a2013.0316, indexed in Pubmed: 24293140.

33. Khazai B, Golden SH, Colangelo LA, et al. Association of endogenous testosterone with subclinical atherosclerosis in men: the multi-ethnic study of atherosclerosis. Clin Endocrinol (Oxford). 2016; 84(5): 700-707, doi: 10.1111/cen.12997, indexed in Pubmed: 26663365.

34. Voigt JU, Pedrizzetti G, Lysyansky $P$, et al. Definitions for a common standard for 2D speckle tracking echocardiography: consensus document of the EACVI/ASE/Industry Task Force to standardize deformation imaging. Eur Heart J Cardiovasc Imaging. 2015; 16(1): 1-11, doi: 10.1093 ehjic/jeu184, indexed in Pubmed: 25525063.

35. Minette M, Hoyer A, Pham P, et al. Cardiac Function in Congenital Adrenal Hyperplasia: A Pattern of Reversible Cardiomyopathy. J Pediatr. 2013; 162(6) 1193-1198.e1, doi: 10.1016/i.jpeds.2012.11.086, indexed in Pubmed: 23337094. 